ARTICLE

DOI: $10.1057 /$ s41599-018-0134-4

\title{
The Franciscan Usus Pauper: using poverty to put life in the perspective of plenitude
}

Willem Marie Speelman ${ }^{1}$

\begin{abstract}
In general, poverty is approached as a pernicious problem. But poverty has always been a spiritual way of life too. For people like Francis of Assisi poverty was not only a problem, but also a mystery of a life in the perspective of perfection. Listening to his story may enrich social, political, and economic approaches to poverty, for it reveals some tactics for turning an obvious curse into a blessing. Focusing on the poor life of Francis and the Franciscans in the thirteenth century, and its early monetary economy, this article tries to come to know, alleviate, and value poverty. Sometimes a phenomenological description is needed to gain a deeper understanding of structures of monetary deprivation, of sharing gifts and needs, and of encountering a mystery. When Francis left the world, he learned that poverty is a fall depriving him of his fundamental relations. But he chose not to approach his poverty as a problem that must be solved, because this would mean that he had to turn himself into a 'priceable object' and 'sell himself'. On the contrary, Francis chose to wait and listen to the voice of God and of the people that he met on the road: poor, merchants, pilgrims, and lepers. He learned that poverty is also a call expressing a longing for presence. Filling the emptiness of this longing with food and things may not be a sufficient response to the calling. Francis's response to the calling transformed the fall into a descent to his own self and to others, and the problem into a mystery. A mystery is not a problem to be solved, but a question calling for an encounter. A first effect of the way Francis lived his poverty was that young men came to join him. They learned that approaching people without having any possessions was a very effective way to truly meet them: poverty revealed in encounters. To live without property became the mission of the brotherhood: an economy of trust, in which the act of sharing gifts, as well as needs was the motor. This mission eventually became a pastoral mission among the people in the cities, especially merchants. Living without property became very easy, because the cities would provide the brothers with everything they needed, and more. To save the original spirit of vivere sine proprio, the Franciscans developed the usus pauper (restricted use), which was a way of living a life in conformity with the poor in their new social and economic environment. In our times, people are learning to re-value practices of 'de-ownership'. The Franciscan practice of usus pauper may help them understand why and how especially someone who lives a life according to the standards of the poor can be there for poor people, and alleviate the poverty that they share: he or she knows his or her real needs, values matters and people realistically, understands the importance of sharing, and is capable of seeing all people and all matters in the perspective of abundance.
\end{abstract}

\footnotetext{
${ }^{1}$ Tilburg School of Theology, Utrecht, The Netherlands. Correspondence and requests for materials should be addressed to W.M.S. (email: w.m.speelman@uvt.nl)
} 


\section{Introduction}

s far back as we can remember, the question of poverty has also been a religious question; just to live, the human being has always been in need of help: from his relatives, the environment, and the divine. Poverty is the human condition of living with all kinds of shortcomings. ${ }^{1}$ In the time of the Biblical fathers, wealth was considered a blessing, poverty a curse (Ryan, 2015). Later, in the time of the prophets, who saw that the wealthy were not always the servants of the Lord, the image of the poor and suffering Servant of the Lord was introduced. Later, Jesus was recognized as this Servant, and the poor were considered to be his brothers. Based on the Gospel of Matthew 25, 31-46, poverty even became the gateway to the kingdom of God, and therefore a vow in religious forms of life. In the thirteenth century, Francis of Assisi - "il poverello" - was a saint, particularly because he was poor with the poor (Lambert, 1998, p 41). And to this day, helping the poor is very often connected with religious motives (Speelman, 2017b). In the light of this, it seems good to delineate how poverty can be described as a spiritual and religious theme, not only as an evil that must be fought, but also however strange this may sound to modern ears - as a virtue and a pathway to a good life. In a spiritual approach, poverty may appear in different forms.

Let me first try to clarify the elusive term 'spirituality'. The most fruitful description of this field seems that of Kees Waaijman, who approaches spirituality as an interactive process between God and the human being, which reciprocally shapes both the divine and human poles of the relationship (Waaijman, 2002, p 430). In other words, when God and Moses communicate which each other, God is becoming more human and Moses is becoming more divine. Of course, this is a religious and theistic approach to spirituality. But consider what happens when a woman talks to a little child: does not she kneel before the child, raise the pitch of her voice a bit and talk in short sentences? And does not the child, at the same time and unconsciously, grow because he is talking to a grown up human being? Spirituality, then, is what happens when a human being gives him- or herself in a relationship and is being shaped through that relationship, while at the same time, as an effect of this communication, the other pole of the relationship (divine, human, or other) is being shaped as well. I therefore propose to use a generic approach in which the spiritual domain is described as a personal engagement which, influenced by cultural and religious environments, shapes the person in question, as well as the reality he or she is engaged with (cf. Wong, 2012, Oosting and Speelman, 2017). Poverty may be such a reality. Poverty is a life situation that any person may be confronted with. But if the person in question chooses to relate him or herself to this situation, even to the extent that he or she chooses to live in poverty, the confrontation may be transformed into an encounter shaping and reshaping the person, as well as his or her poverty. This last element, that both poles of the relationship are being transformed, makes the spiritual process broader and more common than the descriptions of conversion (cf. Paloutzian, 2005).

There are people to whom poverty is not only a problem that must be solved, but also a passage to a new way of life (Schreurs, 2017) or, in Francis's case, in itself a form of life (Todeschini, 2009). Listening to their stories may enrich social, political, and economic approaches to poverty, for it shows how people may find ways to turn an obvious curse into a blessing. In this article I will take the stories about the life of Francis as an example and describe how this thirteenth century citizen, living at the beginnings of the monetary economy, came to know, alleviate, value, and even love poverty. I will listen to stories, that is, I will take a narrative approach to them in the full awareness that the storytellers - mainly three companions who lived with Francis, but also Thomas of Celano in his official vita - have created an image of "their" saint without meeting the historical criteria of our time. ${ }^{2}$ Knowing this, I still believe that the story-tellers tried to express the truth which they found in the life of Francis. ${ }^{3}$ We will see that, in different phases, Francis, as well as his poverty were being shaped, again and again. To put it briefly, in his specific engagement with poverty Francis did not remain alone, for he received brothers who chose to live with him. Francis and his brothers reshaped their poverty into a vow of vivere sine proprio, to live without property as a community, which was seen as one especially attractive variety of being poor (Burr, 2001, p 10). When the brotherhood became a respected religious order (Desbonnets, 1988), and received privileges to offer pastoral care in the cities, their poverty changed (Lambert, 1998, p 71). The brothers may have possessed nothing, but they sometimes received so much, that their poverty was challenged. In order to guard the vow properly, the brothers developed a practice to live a life according to the standards of poor: the usus pauper, poor or restricted use, which admonished them to use only what they really needed, and nothing more. ${ }^{4}$

Based on a narrative analysis of a present day story of a Poor Clare who left the order and fell into poverty (Reyns, 2017, Speelman, 2017a, 2017b), I will distinguish four phases in the spiritual encounter with poverty: a fall, a calling, gaining trust in encounters, and a mission. The fall into poverty, which each of us may experience one day, shows us not only that every buffer with which we protect ourselves may be vanity, but also that the monetary economy which tries to solve the problem of poverty may be a trap in itself: it may only create a new kind of poverty, a materialistic and individualistic one. However, if one does not run away from the problems of the fall, one may hear the call of poverty, either as one's own or someone else's emptiness calling for presence. In listening to the call, poverty is transformed from a problem into a mystery, which in the religious realm is a truth that can only be found when it reveals itself in an encounter. While, according to Karl Rahner, this encounter is ultimately an encounter with God, the Absolute Mystery (Egan, 1998), it is manifested in daily life in encounters with the poor, true encounters in which trust is gained and shared. Their encounters with the poor and with poverty, which they considered in the light of an encounter with Christ, gave Francis and his brothers a mission. This mission could only be carried out by guarding a way of life that conformed to the poor.

\section{Poverty as a fall}

Let us listen to the story of Francis of Assisi, "il poverello", and see how he came to know and even to love poverty, which he sometimes called "Lady Poverty" (SalVirt 2 - see Box 1). Francis was a young citizen of Assisi who had many friends and relatives, and whose father earned a fortune in the cloth trade, and perhaps some less Christian forms of trade (Desbonnets, 1988, pp 11-12). In fact, Francis lived in a period and a region where the modern monetary economy finds its origins (Todeschini, 2009, p 12). But Francis left this world and became a poor man. Whether and to what extent he chose to do this is a matter of discussion. The stories tell us that he tried to find a successful life, and followed his dreams of becoming a knight. But he did not succeed in this project. He became sick, and was told that he followed the wrong lord (3Comp 6 - see Box 1), he was deeply touched by the misfortune of others (3Comp 3; Vauchez, 2012, p 24), and lost the taste for this life (3Comp 8). Some say that war and imprisonment had devastated him (Moses, 2009, p 32). Anyhow, we may say that he failed to realize his dreams, left the world and fell into poverty (Vauchez, 2012, pp 26-27). 
The fall into poverty is the destruction of the integrity of one's life. In one way or another, a living person is taken out of his or her environment in which he or she was related, sharing goods and values. The (new) situation in which this person finds himself as an individual is an empty, abstract space, void of value. Of course, for some people - think of young students - a temporary confrontation with this new, empty situation may feel like a release; for them the emptiness may be a passage to a new life, in which new connections are found and things and people are re-evaluated (Schreurs, 2017), including oneself. In the monetary economy, however, this 'recontextualization' is structured by deprivation (Graeber, 2012, $p$ 229). The individual enters into a world in which everyone and everything is reduced to a quantifiable object. As a quantifiable object you or it can be anything, just like wood can be turned into a house, a chair, or a violin. The young student is successful if he or she is able to gain competencies and sell him- or herself. The fact that so many are not successful and stay poor, and along with them their children and future generations, is generally considered to be a problem that needs to be solved.

In a materialist and individualist context, poverty is a problem, either in the system or in the individual who cannot play the game of materializing and selling him or herself. This problem must be fixed. Overcoming poverty, then, is understood as the disappearance of poverty. When the individual has a job and a place to stay, his or her problem is considered to have been solved. But has it? During the whole process of problem-solving, this person has had the feeling of being a problem. So, when the problem has disappeared, where does that leave him or her? Nobody saw the person, only his problem. And this is a structural thing, an intentionally selective way of looking. For the bureaucracy of our monetary economy discourages interpersonal relations as ineffective in handling the problem. Instead of working with living and vulnerable human beings, we work with problem solving procedures: lists, protocols, and programs (Baart and Carbo, 2013). In fact, the successful have also fallen into a trap, for the 'saved' individual is helped to sell himself, his work is a quantifiable object, and the person ends up being a 'priceable' element that can be replaced at any moment. In our monetary economy, the fall of poverty indeed seems to be a modern form of the mythical fall in Genesis 4: it throws us into original sin.

But Francis did not try to overcome the fall by solving his problems and selling himself to the economy of his time. On the contrary, he left the world of relatives, trade, and war (Micó, 1997), entered into the worthless void and waited for a word of God in his frequent prayers.

\section{Poverty as a call}

After some years of not knowing what to do with his life, Francis heard Christ speaking to him with an inner voice and in encounters with the poor and excluded (3Comp 5-6; 11, pp 1314). One of the stories about his conversion recounts that Francis overheard the Gospel of Jesus sending his disciples to proclaim the Gospel (3Comp 25-29; 1 Cel 22 - see Box 1). He was especially touched by the passage: "take nothing for your journey". Now he knew what to do with his life: it would be a journey without any property. Poverty appeared to him, and eventually to his brotherhood, as a call.

Poverty as a call at first appears as an emptiness in one's life calling for a presence. One may respond to this call by ceaselessly filling the emptiness with things that do not bear a presence. Or one may experience it as a free space just to be, passing to a new and more meaningful life. Listening to the call, the individual begins to understand that it is a call for his or her presence. The call may also be heard when one experiences the poverty of others and feels the need to be present to them. Again, filling the poverty of others with things that do not bear your presence is not an apt response to that call. The first reshaping effect of this is that, responding to that call and Francis's presence, brothers came to live with him. In response to poverty becoming a call, Francis became a brotherhood (Speelman 2010, pp 44-53).

Francis's reaction to the words "take nothing for your journey" points to an interesting aspect of the call of poverty. Poverty is also a competence to be able to hear the call, for nothing hinders the senses. Poor and pure ears appear to be more sensitive to calls that rich and occupied ears do not seem to hear. This positive effect of poverty is, as we will see, the main argument why Peter John Olivi (1248-1298) considered the usus pauper as integral to the Franciscan vow of living without property: it is a way of life in which the friars perceive reality more sensitively and more realistically (Speelman, 2016). As a sense organ, the body functions better when it is naked and needy, for the bodily response to the feeling of a lack is to become more sensitive. As a result, Francis and his brothers experienced that it was easier to meet other people, poor as well as rich, when they had nothing impeding their senses and obstructing their relations. Where the fall into poverty is felt merely as a problem that elicits a desire to get out of the situation, the call of poverty will elicit a different response: one of sensitive presence. Francis expresses this presence by calling his poverty a Lady (SalVirt 2 - see Box 1) or by connecting it to the poverty of Christ and His Mother (2EpFid 5 - see Box 1 ). A call turns poverty into a mystery, and a mystery demands a sensitive ear.

In his Encyclical Laudato si, pope Francis writes that the world is more than a problem, as it is also a mystery (LS 12). If a problem is approached as a mystery, the one who is having the problem is central to its solution, not by conquering the problem though, but by listening to its message. As mentioned, a mystery is a sign of a truth that can only be known when it reveals itself.

\section{Box 1: | Abbreviations}

1Cel FAED I (1999) The Life of Saint Francis by Thomas of Celano, in Francis of Assisi: Early Documents. In: Regis J Armstrong, JA Wayne Hellmann, William J Short (eds) The Saint, vol I. New City Press, New York, pp 169-257

3Comp FAED II (2000) The Legend of the Three Companions, in Francis of Assisi: Early Documents. In: Regis J Armstrong, JA Wayne Hellmann,

William J Short (eds) The Founder, vol. II. New City Press, New York, pp 59-110

AC The Assisi Compilation, in FAED II, pp 113-230

1EpFid Epistola ad Fideles I. Earlier Exhortation, in FAED I, pp 41-44

2EpFid Epistola ad Fideles II. Later Admonition and Exhortation, in FAED I, pp 45-51

Fior Fioretti. FAED III (2001) The Little Flowers of Saint Francis, in Francis of Assisi: Early Documents. Vol. III, The Prophet, In: Regis J Armstrong, JA

Wayne Hellmann, William J Short (eds) New City Press, New York, pp 566-658

RB Regula Bullata. The later Rule, in FAED I, pp 99-106

RnB Regula non Bullata. The earlier Rule, in FAED I, pp 63-86

SalVirt Salutatio Virtutum. A Salutation of the Virtues, in FAED I, pp 1641-65

Test Testamentum. Testament, in FAED I, pp 124-127 
For example, the mystery of the Trinity is not a mathematical problem in which $3=1$ and $1=3$, but it is a divine countenance that calls the attention of the faithful, without them being able to grasp it. Not only God - "the Absolute Mystery", according to Rahner - but also the world or a person or a situation can be approached as a mystery. The person who is confronted with his needs becomes sensitive to the true nature of his situation, but also to his or her own nature as a human being. Thus, in a mystery two countenances enter into an encounter. In this encounter, life itself calls the human being to be human and alive. Again, this is more than a one-sided conversion, for the mysterious reality is transformed as well: by revealing itself.

This call for a human life brings us to an approach to poverty in which the soul matters, if only by showing us who we really are. David Graeber introduces, apparently in opposition to today's individualism, the somewhat polluted term 'communism', in which individuals share their gifts and needs "from each according to their abilities, to each according to their needs" (Graeber, 2012, p 94). He calls this communism "the foundation of all human sociability" (96). This means that our motivation comes from within: we do these things just because we are human. And our humanity is still calling us. Apparently, especially poor people, thrown back on their naked humanity, can be sensitive enough to hear this call. Perhaps it is poverty itself which reminds them of their original state, in which human beings are quite capable of living with all kinds of shortcomings.

\section{Poverty as an encounter that generates credit}

When Francis lived on the road, he of course met other people of the road: the poor, merchants, pilgrims, and lepers. And his sensitive ears heard their calls. In the story of Francis's encounter with the leper, the call is suggested to transcend human relations: it was suspected that in this leper he met the Lord.

One day he was riding his horse near Assisi, when he met a leper. And, even though he usually shuddered at lepers, he made himself dismount, and gave him a coin, kissing his hand as he did so. After he accepted a kiss of peace from him, Francis remounted and continued on his way. (3Comp 11)

To understand the rich symbolism in this story, we should be aware of some strong Christian motives. In the psalms and the prophets the poor and the needy become the focus of God's care. And in pseudo-Isaiah, the servant of God appears as the one who through humiliation remains faithful to God. In Isaiah 53:4 (Old vulgate) this servant is called a 'leper' (leprosum). In Matt 12:1521 Jesus is recognized as the servant of God. Add to this mindset the symbolism of the hand kiss, which is given to the Pope as the vicarius Christi, and the kiss of peace, which is a Eucharistic act. Reading the short story of the encounter with the leper against this symbolic background, the association of this leper with Christ is not far-fetched. The message of stories like this is that God's kingdom is His nearness, even in the figure of a leper. He is with you in wealth and in poverty, as a foreigner in whom you can recognize yourself (Lev 19:18.34; Luke 10:27).

The transcendental layer of human relations, and in the case of Francis even encounters with other creatures like birds (1Cel 58; Fior XVI - see Box 1) or a wolf (Fior XXI), confirms and reinforces the idea that Francis did not perceive outcasts as problems, but as a mystery, a divine mystery, for he recognized Christ and the Creator in them (Micó, 1997, Burr, 1975). The young men who chose to join him in living a life in conformity with the poor were also welcomed by Francis as a gift from the Lord (Test 14 see Box 1). The fall into poverty had been transformed into a call, and the call into a descent: a slow and peaceful going deep to meet the needy in order to lift them up towards the good life. All kinds of needy people, rich and poor, learned and illiterate, noble and humble, men and women (1Cel 31) started to join, each in their own way, in an endlessly growing brotherhood. Meanwhile, poverty revealed itself in a series of encounters, which were always considered in the light of an encounter with the poor Christ.

Francis encountering poverty shaped Francis, as well as poverty: Francis became 'il poverello' and 'il fratello' (the little poor one and the little brother), and poverty became a form of life called vivere sine proprio, a life that attracted many and enhanced encounters. Living without property does not mean that you have nothing to give, but that you have nothing to sell (Graeber, 2012, p 206). Essentially, Francis and his brothers had resigned to the right to sell, not only individually, but also as a community. This resignation can be recognized in the story of someone sarcastically saying: "You might tell Francis to sell you a penny's worth of his sweat" (3Comp 23). They resigned the right to sell, but did not refuse to receive. On the contrary, they received people and their benevolent gifts and needs: they lived by the daily work of their hands, and if not, by what the people would offer them, when they begged "from door to door" (3Comp 22; 1Cel 34). Their daily encounters were full of exchange, which is the basic economic process (Poggi, 1993, p 95). This form of exchange, however, was a gift without expectation of a well-counted return (contra Mauss, 2002). This way, the exchange did not create a debt, but transformed it into a responsibility and an obligation (Graeber, 2012, p 144). As the focus is not on priced goods and services but on human relations, a true encounter is a genuine act of giving and receiving, namely sharing each other's presence in which gifts, as well as needs are exchanged. As long as this act is not frustrated, it generates an unlimited sharing community and an economy in the perspective of plenitude. For a single gift can help many people, and thus grow. It does not materially grow into more of what there is to share, but the act of sharing turns what there is into an abundance.

Writing his Testament, Francis remembers that he received his new life from the Lord: "Dominus dedit mihi..." - "The Lord gave me..." (Test 1). He received God's gifts together with what Thomas Aquinas called their inclination to be shared (ST 1, q.19, a.2; q.38, a.1). Living without property, Francis and his brothers avoided turning a gift into property. On the contrary, they would immediately return the gift by giving it away or sharing it with others. In this way, the gift remained a gift, and the act of giving and receiving continued. It is like the ball in a game: its meaning lies its being moved between the players; he who keeps the ball for himself frustrates the game. What is highlighted, then, in the act of giving and receiving is the interpersonal relation - the encounter - in which the gift functions as a medium. The medium represents the giver, as well as the receiver: they both give themselves and receive one another in one and the same act of giving. They both respond to the act of giving by receiving, sharing, and returning what was received. In this continued process of communication trust will grow. Francis believed, and this is essential, that the Lord is the ultimate origin and destination of this trust ( $\mathrm{RnB}$ 17:17 - see Box 1).

The spiritual exchange that Francis and his brothers practiced was a sharing of trust ('credit'). The shared gift is trust, an "I trust you with this". In response to the poverty they encountered, they practiced trust, and endured the opposite: loss, distrust, and theft. To practice trust can only be done by receiving trust, trust being precisely that which is being shared. Thus, Francis and his brothers engaged in living among the people. Having become poor with the poor, they were received well and built up an enormous amount of credit. People felt responsible for them, and many wanted to join them. We will see, however, that the 
authorities of the Church and the City also wanted to use them and their credit, which threatened to frustrate their original spirituality.

\section{Poverty as a mission}

In the stories about Francis and his brothers hearing the Gospel in which Jesus sends his disciples out to the world, taking nothing with them, they had already heard their mission in life. But analyzing the gift as an act, we have seen that this mission is already given with the gift which, in order to remain a gift, motivates the receiver to share. And as Francis and his brothers recognize the Lord giving Himself in the gifts, as well as the needs, the human act of giving and sharing has a transcendent perspective: it is a sharing without end, until it is returned to the Lord.

These lines call for a moment of discernment, for do not they actually describe the phenomenon of money? Is not a coin a gift that needs to remain a gift in order to be valuable: constantly being spent and earned? And is not the monetary economy, which the merchants of Francis's time were developing, a sharing without an end? We should not forget that Francis of Assisi started his life as a merchant; and merchants showed that wealth could be gained, in a paradoxical way, by actively and creatively living a life in conformity with the poor: not possessing, but constantly spending and earning (Todeschini, 2009, p 28). Giacomo Todeschini writes: "People started thinking that, thanks to poverty, it could be easier to use wealth and to circulate it, managing the reality without taking possession of it (2009, p 76)." Needless and yet important to say that there were the poor who could and the poor who could not live a mobile, active, and creative life (Todeschini, 2009, p 35).

There is an important difference between 'credit' and 'debt' in the monetary sense and 'credit' and 'debt' in the spiritual sense: the debt in monetary sense can be and will be counted (Todeschini, 2009, p 12), but a debt in the form of responsibility cannot be counted. I know exactly how much I owe the bank, but this is not the same thing as how much I owe my daughter. I feel responsible for my daughter, not to the measure that I owe her a certain amount of love, but to the extent that she needs my care, and more. In the final paragraphs I will argue that poverty is especially a mission to those who have experienced it in the perspective of abundance, in the sense that they are responsible for guarding and keeping this perspective. This means that the act of giving and receiving is carried out in such a way that it does not incur a certain amount of debt, but a growing responsibility; that a gift, as well as a need, will be shared and not turned into property (debt being the need turned into property); that the receiver participates in the giving and the giver in the receiving. We have seen that a true relationship shapes both the participants in the relationship, matching them to one another. Therefore, the mission to live with the poor will turn all the participants into brothers and sisters sharing their poverty and their wealth. This explains the somewhat paradoxical dream of Pope Francis of a poor Church for the poor in order to alleviate poverty (Speelman, 2017b). ${ }^{5}$

Poverty as a mission turns people's shared vulnerability into sensitivity. I have already noted that poverty as a call elicits the response of a sensitive ear. Here, this sensitivity has grown into a more general responsibility. Next to the responsibility to guard the act of giving and receiving and keep it safe from appropriation, the person who lives with the poor and outcasts is sent and able to approach them sensibly because he or she knows where it hurts and can show compassion where it is needed. If this is done well, their mission will be returned as trust, for it is clear that there is a mutual understanding and that the compassion is genuine. In this respect it is a good thing that caregivers can feel pain and troubles; it is essentially part of their profession, or at least their mission.

In their rule, the Franciscan friars are called to share each other's needs (RnB 9:10; RB 6:8 - see Box 1). If someone wants to share his needs, he has to know what his personal needs are, and that they may be different from the needs of others. Thus, he comes to know his own vulnerability, and to value the needs of others. Again, the needs are not approached as a problem, but as signs of a mystery (Micó 1997, p 275). When Francis hears a hungry brother call "I'm dying, I'm dying of hunger," he does not only feed this brother - which would solve his problem - but instead, feeds all the brothers and tells them to listen to the needs of their own body (AC 50 - see Box 1). The whole sense of a penitential life is that by an encounter with one's own neediness, one comes close to the neediness of others, and in doing so, to the neediness of the poor Christ (Matt 25:40). Just as the gift may bring the receiver into contact with the giver, sharing one's need is a form of intimate contact (Todeschini, 2009, p 30). Therefore, as we will see in the practice of the usus pauper, the task of the friars, individually and collectively, was to remain in a state of need, to use it in order to stay in tune with the needy and to do this in the perspective of the perfection of the holy Gospel, which is Christ.

The poverty of the friars minor of the thirteenth century, which as we have seen had been transformed into a competence in their pastoral mission, may shed a new light on the biblical sentence that poverty will not be wiped out from the earth: "the poor will always be with you" (Deut 15:11; Mark 14:7). For in a way, the poor and the weak have something very important to give in their vulnerability: their call keeps the mission alive to search for the true values in life. They represent a place where divine compassion and communion can be found. Their vulnerability forms a key for understanding the Gospel. In Evangelii Gaudium Pope Francis writes: "Without the preferential option for the poor, 'the proclamation of the Gospel...risks being misunderstood or submerged'." (199). And when Christ preached to the poor that they will share in the kingdom of God, to the diseased that they will be healed, and to the sinners that they will be forgiven, He did more than promise them that everything would be all right in the afterlife: the kingdom of God is a way of life in which people are received in the grace of God, and - with all the sensitivity that their vulnerability gives them - respond to this grace by sharing it.

\section{Transformation of vivere sine proprio into usus pauper}

The friars were sent into the world to share the blessings of the Franciscan life. An important and attractive blessing had been their ability to live without any property. People, among them many merchants, were touched by their message, and came to them for confession and spiritual guidance (Piron, 2012, p 40). These people were eager to live a perfect life, but could not or did not want to leave the world in which they carried daily responsibilities and had their dreams (Little, 1975, p 17). They had to find perfection in their imperfect situations: to live a perfect life with property. Francis had written a letter to the faithful (1EpFid, 2EpFid - see Box 1), in which he admonished every faithful Christian to live a life in penitence, but he failed to translate the Franciscan form of life into the situation of the thirteenth century monetary economy (Todeschini, 2009, p 92). He could not have done that, because it was a new poverty.

This failure, however, turned into a problem, especially because the authorities of the Church, as well as the City noticed the success of the friars and gave them an important pastoral task, thereby providing them with everything that they would need to 
perform this task: privileges, prestige, food, goods, and houses (Todeschini, 2009, pp 80-82). This led the friars minor into a fierce struggle about their spirituality. The solutions of Pope Gregory IX in his bull Quo Elongati (1230) and Bonaventure in his Apologia Pauperum (1269) - making a distinction between dominion and use - were too academic for simple brothers (Lambert, 1998, p 128). For what is the point of vivere sine proprio if a friar, instead of being poor with the poor (Lambert, 1998, pp 54-55), lives the life of a wealthy man? He may not possess anything, but is able to use and enjoy the wealth of the church, the city, and spiritual friends. Whereas the people in the cities tried to live a perfect life in an imperfect situation, the Franciscans threatened to live an imperfect or even sinful life in the perfect setting of "the life of the Gospel of Jesus Christ" (RnB, prologue, 2 ). The friars, therefore, felt the need to guard the perfection of their vow (Burr, 2001, pp 9-10) and flee the danger of mortal sin, because their task in the world obliged them to disobey their vow.

To save their vow to vivere sine proprio, in practice, as well as in spirit, the Franciscans developed the usus pauper - poor or restricted use - as a new way of life in a new social and economic environment (Burr, 1989). The usus pauper let the friars use the things that were offered to them only to the extent that they met their needs to live and to perform their (pastoral) tasks. The intellectual but also controversial friar Peter John Olivi had a distinctive view on the usus pauper. On the one hand, he unambiguously argued that the usus pauper was integral to the Franciscan vow of vivere sine proprio, meaning that if Franciscans stopped living a life according to the standards of the poor, they would disobey their vow and be living in a state of mortal sin. On the other hand, Olivi considered the vow of vivere sine proprio including usus pauper in the light of its origin, which is an evangelical counsel. In a vow the counsel has become a precept, but the fulfillment of this precept is dependent on the context. This means that, for example, a Franciscan bishop might be obliged to live in a way that would be absolutely sinful if adopted by a normal brother in a small Franciscan house. David Burr writes: "For Olivi the vow is not so much a contract concerning specific behavior as the beginning of a spiritual quest" (2001, p 53): do I really need this to live and perform my task?

We have seen that vivere sine proprio and usus pauper are two forms of what may be called 'positive poverty', a poverty that is meaningful in the perspective of a good life, but that these forms are highly dependent on the context in which they are lived. Can these late medieval forms be of any value in our situation? I think they can. The friars minor of the thirteenth century combined a religious form of life with a life among the poor. This gave them an in-between position, in which they experienced the needs, as well as the gifts of the people, and viewed this experience in the perspective of a life according to the perfection of the holy Gospel (Todeschini, 2009, pp 86-88). ${ }^{6}$ The friars minor were capable of looking realistically at the daily reality, for example of the merchants, and valuing their deeds in the light of perfection: "What is your sin really?" This made them living examples and reliable guides for the faithful. Therefore, Olivi argued that the poverty of bishops and friars is not a problem that must be solved, not even a commandment that must be fulfilled, but that it instead is a precious thing in its own right, which must be kept and guarded as a gateway to the poor and to perfection. He or she who recognizes this form of poverty, will not define the poor by their needs or consider them as a problem. On the contrary, they will be recognized as people of great value, who have much to give. And this may be as true now as it was then. And is this not the truth behind the dream of Pope Francis, for a poor church for the poor?

A poor church will discern the depth of the fall of poverty, and refuses to sell herself as a priceable spiritual or social service on the market. She will listen to the call of poverty: for presence, not for material promises that in fact increase the needs. Living with the poor, she will grow in communion, sensitive to her own gifts and needs, as well as the needs and gifts of others. She will be aware of poverty, and especially the poor, as a mystery instead of a problem. And she will see to it that a gift remains a gift, and is continuously being shared.

\section{Conclusion}

We have seen that a spiritual approach to poverty, as it was practiced by Francis and his brothers, reshaped the Franciscans, as well as their poverty. I will summarize how both Francis and his poverty changed. At first, when Francis fell into poverty, poverty revealed itself as a problem and Francis became a priceable, i.e., worthless, object. But then, when Francis refused to solve the problem and listened to the call of poverty, it appeared to him as a mystery and he became a sensitive person listening to its message. In a series of encounters, which Francis often considered in the light of an encounter with the poor Christ, poverty became a choice to live without property, and Francis became a brother. Finally, when Francis and his brothers came to understand their mission, poverty itself became a mission to live a life in conformity with the poor in the perspective of the perfection of the holy Gospel. In the practice of usus pauper the Franciscans kept and guarded their poverty as a precious thing, making their environment appear as a plenitude of valuable creatures (Burr, 1975).

Although today religious faith is considered no more than an option to the modern individual (Taylor, 2007, p 3), the Church has been transformed into a more modest presence in society (Hellemans, 2010), and the Franciscan orders are declining rapidly in the Western world, the voice of this tradition is still worth being heard. Especially the Franciscan tradition has a history of overcoming poverty, not only by combatting societal or economic structures which throw people into a state of deprivation and debt, but also and especially by entering into a spiritual relationship with the poor and with poverty itself. In this relationship we will hopefully find our own late modern form of Franciscan poverty and restricted use.

Received: 18 October 2017 Accepted: 14 May 2018

Published online: 26 June 2018

\section{Notes}

1 The Unesco document Learning to live together admits that there is no international consensus on guidelines for measuring poverty. See: http://www.unesco.org/new/en/ social-and-human-sciences/themes/international-migration/glossary/poverty [accessed on April 18, 2018]. On the description of poverty, see Clemens Sedmak, Armut als komplexes System: materiell, sozial, ökonomisch, spirituell-eine theoretische Begriffsbestimmung, In: Speelman WM, Hilsebein A, Schmiess B, Schimmel Th (eds) Poverty: As Problem and as Path/Armut: Als Problem und als Weg. Aschendorff/Franciscan Institute Publications: Munster/St. Bonaventure, 2017, pp 23-33. As a point of departure Sedmak describes poverty as a life situation that is characterized by shortcomings.

2 Thomas of Celano wrote the official Life of St. Francis with the intention to picture the life of a saint, whereas the three companions - the brothers Leo, Rufinus, and Angelus - collected stories "for the praise and glory of almighty God and of the holy father Francis, and for the edification of those who desire to follow in his footsteps." (Introductory Letter to 3Comp).

3 The question of truth in narratives is discussed in Heikkinen et al. (2001)

4 On the history of this term and its reception, see Lambert 1998.

5 www.reuters.com/article/us-pope-poor-idUSBRE92F05P20130316 (Accessed 21 Jan 2018).

6 This formulation can be found in the Form of Life of St. Clare (FLCl 6:3), where she quotes St. Francis. See Form of Life, in Clare of Assisi, The Lady. Early Documents. Revised edition and translation by Regis J. Armstrong OFMCap, New York: New City 
Press, 2005, pp 106-126. On the theme of evangelical perfection in early Franciscan documents, see Lapsanski DV (1974) Perfectio evangelica. Eine begriffsgeschichtliche Untersuchung im frühfranziskanischen Schrifttum, Schöningh: München.

\section{References}

Baart A, Carbo C (2013) De Zorgval. Thoeris, Amsterdam

Burr D (1975) Poverty as a constituent element in Olivi's thought. In: Flood D(ed) Poverty in the middle ages. Dietrich Coelde, Werl, p 71-78

Burr D (1989) Olivi and Franciscan poverty: the origins of Usus Pauper controversy. Penn Press, Philadelphia

Burr D (2001) The Spiritual Franciscans. From protest to persecution in the century after Saint Francis. Penn Press, Philadelphia

Desbonnets TH (1988) From Intuition to Institution. The Franciscans. Franciscan Herald Press, Chicago

Egan HD (1998) Karl Rahner: mystic of everyday life. Crossroad, New York

Oosting E, Dronkers J, Hoogeboom Th, Van Meeteren N, Speelman WM (2017) Personal meaning in relation to daily functioning of a patient in physical therapy practice. narratives of a patient, a family member and physical therapist. Disability Rehab https://doi.org/10.1080/09638288.2017.1290153

Oosting E, Speelman WM (2017) Personal meaning: van Narratieve analyse tot Geestelijke Zorg. Relig En Samenlev 12(2):182-200

Graeber D (2012) Debt: the first 5,000 Years. Melville House Publishing, Brooklyn

Heikkinen HLT, Kakkori L, Huttunen R (2001) This is my truth, tell me yours: some aspects of action research quality in the light of truth theories. Educ Action Res 9(1):9-24. https://doi.org/10.1080/09650790100200142

Hellemans S (2010) Das Zeitalter der Weltreligionen. Ergon, Würzburg

Lambert MD (1998) Franciscan Poverty. The Doctrine of the Absolute Poverty of Christ and the Apostles in the Franciscan Order 1210-1323. Franciscan Institute Publications, St. Bonaventure

Little L (1975) Evangelical poverty, the new money economy and violence. In: Flood D (ed) Poverty in the middle ages. Dietrich Coelde, Werl, p 11-26

Mauss M (2002) The gift: forms and functions of exchange in Archaic societies. Routledge, London

Micó J (1997) Franciscan poverty. Greyfriars 11:257-300

Moses P (2009) The Saint and the Sultan. The Crusades, Islam and Francis of Assisi's Mission of Peace. Doubleday Religion, New York

Paloutzian RF (2005) Religious conversion and spiritual transformation. a meaning-system analysis. In: Paloutzian RF, Park CL(eds) Handbook of the psychology of religion and spirituality. Guilford Press, New York/London, $\mathrm{p}$ 331-347

Piron S (2012) Présentation. Pierre de Jean Olivi Traité Des Contrats. Les Belles Lettres, Paris

Poggi G (1993) Money and the Modern Mind. Georg Simmel's Philosophy of Money. University of California Press, Berkeley

Reyns Ch (2017) He was constantly there. In: Speelman WM, Hilsebein A, Schmiess B, Th Schimmel(eds) Poverty: As Problem and as Path/Armut: Als Problem und als Weg. Aschendorff/Franciscan Institute Publications, Munster/St. Bonaventure, p 403-404

Ryan PJ (2015) Poverty: The Curse and the Blessing. Jewish, Christian, and Muslim Perspectives. Fordham University, New York.

Schreurs J (2017) Budget circles and the lift-your-life method: a sustainable lifestyle perspective on pathways out of poverty. In: Speelman WM, Hilsebein A, Schmiess B, Th Schimmel(eds) Poverty: As Problem and as Path/Armut: Als
Problem und als Weg. Aschendorff/Franciscan Institute Publications, Munster/St. Bonaventure, p 313-328

Speelman WM, Freeman GP, Van den Eijnden J (2010) Om de hele wereld. Inleiding in de franciscaanse spiritualiteit. Valkhof, Nijmegen

Speelman WM (2016) The Franciscan Usus Pauper as the Gateway towards an Aesthetic Economy. Francisc Stud 74:185-205

Speelman WM (2017a) Half Her Knee. Description of the Spiritual Dimension of a Physiotherapeutic Case. In: Hense E, Hübenthal Ch, Speelman WM(eds) The quest for quality of life. approaches, concepts and images with a special focus on the Netherlands. Aschendorff, Munster, p 79-93

Speelman WM (2017b) The Dream of Pope Francis of a Poor Church for the Poor. In: Speelman WM, Hilsebein A, Schmiess B, Th Schimmel(eds) Poverty: As Problem and as Path/Armut: Als Problem und als Weg. Aschendorff/Franciscan Institute Publications, Munster/St. Bonaventure, p 405-422

Taylor Ch (2007) A secular age. Belknap Press Harvard University, Cambridge

Todeschini G (2009) Franciscan wealth. From voluntary poverty to market society. Franciscan Institute Publications, St. Bonaventure

Vauchez A (2012) Francis of Assisi. The life and afterlife of a medieval saint. Yale University Press, New Haven, London

Waaijman K (2002) Spirituality. Forms, foundations, methods. Peeters, Leuven

Wong PTP (2012) The human quest for meaning: theories, research, and applications, 2nd edn. Routledge, New York/London

\section{Data availability}

Data sharing is not applicable to this paper.

\section{Additional information}

Competing interests: The authors declare no competing interests.

Reprints and permission information is available online at http://www.nature.com/ reprints

Publisher's note: Springer Nature remains neutral with regard to jurisdictional claims in published maps and institutional affiliations.

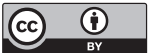

Open Access This article is licensed under a Creative Commons Attribution 4.0 International License, which permits use, sharing, adaptation, distribution and reproduction in any medium or format, as long as you give appropriate credit to the original author(s) and the source, provide a link to the Creative Commons license, and indicate if changes were made. The images or other third party material in this article are included in the article's Creative Commons license, unless indicated otherwise in a credit line to the material. If material is not included in the article's Creative Commons license and your intended use is not permitted by statutory regulation or exceeds the permitted use, you will need to obtain permission directly from the copyright holder. To view a copy of this license, visit http://creativecommons.org/ licenses/by/4.0\%.

(C) The Author(s) 2018 